\title{
Postpartum women in the Honduran health system: folic acid knowledge, attitudes, and practices
}

\author{
Gayle R. Milla, ${ }^{1}$ Alina L. Flores, ${ }^{2}$ Edgardo Umaña, ${ }^{1}$ Ileana Mayes, ${ }^{1}$ \\ and Jorge Rosenthal ${ }^{2}$
}

Suggested citation

Milla GR, Flores AL, Umaña E, Mayes I, Rosenthal J. Postpartum women in the Honduran health system: folic acid knowledge, attitudes, and practices. Rev Panam Salud Publica. 2007;22(5):340-7.

\begin{abstract}
Objectives. This study had two purposes: first, to determine the knowledge, attitudes, and practices related to folic acid and birth defects among a convenience sample of postpartum Honduran women; and second, to identify food consumption patterns in this population and determine high-consumption staples for potential folic acid fortification.

Methods. Convenience sampling methodology was used to recruit potential study participants. Participants for this study were 2619 postpartum Honduran women who had had a normal, in-hospital delivery in one of 16 public hospitals located throughout the country or the two social security hospitals that provide services to the Honduran working class population. Over a 10-month period, in-depth, face-to-face oral interviews, supervised by the research coordinator and staff, were conducted in-hospital prior to discharge.

Results. The majority of the women were between 16 and 29 years of age. Approximately half of the respondents $(46.4 \%)$ had heard of folic acid and over one-third (37.6\%) knew that it was a vitamin related to preventing birth defects. Birth defects were most often attributed to drug and alcohol use (20.6\%) and lack of vitamin intake $(18.1 \%)$, but $23.0 \%$ related defects to mystical, mythical, or religious causes. Aside from red beans, oranges, and natural fruit juices, folate-rich foods are not widely consumed by this population. The highest consumption frequency of staple foods with the potential to be fortified with folic acid were rice, white flour, corn flour, and pasta.

Conclusions. Results from this study provide potential avenues for food fortification, as well as underscore the need for further education about the role of folic acid in the prevention of neural tube defects. Results highlight that standardized health education for Honduran women of reproductive age is needed if folic acid consumption through fortification and supplementation is to be successful and sustainable.
\end{abstract}

Key words Folic acid, prenatal nutrition physiology, neural tube defects, Honduras.

1 Proyecto Niños Saludables/Project Healthy Children, San Pedro Sula, Honduras. Send correspondence to: Gayle R. Milla, 5 Avenida entre 7 y 8 Calle N.O. \#80, Barrio Guamilito, San Pedro Sula, Honduras; telephone/fax: 0115045504795 email: gmilla@projecthealthychildren.org.

2 National Center on Birth Defects and Developmental Disabilities, Centers for Disease Control and Prevention, Atlanta, Georgia, United States of America.
In 1992, the United States Public Health Service recommended that all women of childbearing age consume 400 micrograms of synthetic folic acid daily to prevent neural tube defects (NTDs), namely spina bifida and anencephaly (1). Although the rates of
NTDs in the United States have decreased since fortification of the food supply with folic acid, rates among Hispanics in both Latin America and the U.S. have remained high compared to those of non-Hispanic blacks and whites (2-4). The exact reasons for this 
disparity remain unclear, but research conducted with Hispanic women in the United States has indicated that levels of folic acid awareness, knowledge, and consumption are lowest among this population (5-10). A 1998 survey conducted by the Gallup Organization (Washington, DC, United States) for the March of Dimes Birth Defects Foundation found that English-speaking Hispanic women had lower folic acid awareness (53\% vs. $72 \%$ ) and lower daily consumption (29\% vs. 33\%) than non-Hispanic white women (5).

In Honduras, one of the poorest countries in the Western Hemisphere, the infant mortality rate is 30.8 per 1000 live births (2004 data), with the highest number of deaths occurring in the neonatal period (11). The current prevalence of NTDs in Honduras is estimated to be 2.43 per 1000 births, with the highest rates occurring in the country's poorest health regions (12). Although there is no systematized monitoring system for NTDs in Honduras, a 1-year retrospective review of patient records in four Honduran specialized public health hospitals and the two social security hospitals showed that $49 \%$ of deaths associated with birth defects were due to NTDs (13).

Socioeconomic factors contribute to the health issues faced by many Hondurans. Forty-one percent of the population is under 15 years of age and almost one-half of births occur at home, without prenatal care (11). Underreporting of births and deaths is estimated to be $40 \%$ and $52 \%$, respectively (14). More than half of the population lives in rural areas. Seventy percent of the population lives in poverty, with half of that cohort living at the extreme poverty level (15). Furthermore, 1 in 5 people over 15 years of age is illiterate (11). These factors challenge the success of even the best-designed health education efforts.

Although a dietary intake study of Honduran women was conducted by Holden and colleagues (16), a review of the literature indicates that there are no published reports focusing solely on Honduran women's levels of folic acid knowledge and awareness or syn- thetic folic acid consumption. In August 2004, Proyecto Niños Saludables / Project Healthy Children surveyed 219 women of childbearing age in two public hospitals and four outpatient health care centers in one health region. Of the women interviewed, 50\% reported having heard about folic acid and $25 \%$ of these connected it with the prevention of congenital anomalies (17).

In the United States, folic acid fortification has successfully increased folic acid consumption. Countries such as Chile and Canada have also decreased NTDs though flour fortification programs $(18,19)$. In January 2003, mandatory fortification of wheat flour with folic acid at a level of $1.8 \mathrm{mg} / \mathrm{kg}$ was legislated in all Central America (20). Wheat flour had been voluntarily fortified with $1.4 \mathrm{mg} / \mathrm{kg}$ as part of a vitamin pre-mix recommended by the Nutrition Institute of Central America and Panama (INCAP) since 1996 (21; Dr. Doris Chinchilla, personal communication, February 2006). Currently, MASECA, one of four corn flour products in Honduras, voluntarily fortifies its product with folic acid (22). The Honduran Ministry of Health is negotiating with all of the country's corn flour and pasta producers in an effort to legislate fortification with folic acid (Dr. Vilma Estrada, personal communication, October 2005; Dr. Luis Medina, personal communication, September 2005).

In 2003 the Ministry of Health of Honduras approved the use of folic acid for all women of childbearing age for the prevention of birth defects; however, Public Health Norm 3.2, which regulated the recommended use of folic acid for this population at $1.0 \mathrm{mg}$ per day, was not published until August 2005 and has yet to be adopted throughout the health system (23). Currently, women who appear at a public health center for their first prenatal care visit are given $1.0 \mathrm{mg}$ tablets of folic acid for daily consumption (24). However, this first prenatal care visit most often occurs late in the pregnancy, well past the first trimester (25). Because NTDs occur very early in pregnancy, before a woman knows she is pregnant, folic acid consumption must take place before conception and throughout the first trimester to be effective (1). Giving women folic acid before conception provides the greatest window of opportunity for preventing NTDs.

The purpose of this study was twofold: (1) to determine the levels of folic acid awareness, knowledge, and practices among a sample of postpartum Honduran women, so that a baseline for future educational efforts might be established; and (2) to understand the food consumption patterns of this population so that staples for folic acid fortification might be identified.

\section{MATERIALS AND METHODS}

\section{Participants}

Convenience sampling methodology was used to recruit study participants. Potential participants for this study were postpartum Honduran women who had delivered in 1 of 18 hospitals throughout the country (Table 1). Eligible participants were defined as Honduran postpartum women of any age who had had a normal in-hospital delivery without complications. Interviews were conducted with participants just prior to discharge from the hospital. Eligible participants had to be able to provide information themselves; information volunteered by family members was not accepted.

\section{Procedure}

The concept for the structure of the study was derived from a telephone communication with Dr. Cathy R. Wasserman of the Washington State Department of Health (United States) in August 2000. The Honduran Minister of Public Health gave the research coordinator permission to conduct interviews in the public health and social security hospital systems. Study protocols were approved by the Ethics Committee of the Scientific Research Unit at 
the National Autonomous University of Honduras' School of Medicine (Facultad de Ciencias Médicas, Universidad Nacional Autónoma de Honduras (UNAH)). Once permission was granted and the protocols approved, an interview schedule was developed and interviewers were recruited from within the hospital system. Sixteen of the hospital sites were public hospitals dispersed throughout the country and the remaining sites were the two social security hospitals that provide services to the Honduran working class population. These sites represent $64.3 \%$ of the hospitals in the public health system and $100 \%$ of the hospitals in the social security system.

\section{Survey instrument}

All items for the survey instrument, except sociodemographic and food frequency items, were based on existing research related to congenital anomalies, NTDs, and folic acid (26-37). Because no food frequency or diet assessment tool had been used before with Honduran women, the investigators developed a new instrument from tools previously used by experts in the United States (Dr. Catherine Hayes, personal communication, September 2000; Dr. Maria Tolarova, personal communication, November 2000). Food consumption items were adapted to include those foods commonly consumed by the Honduran population.

The initial instrument was tested in two Honduran public health hospitals prior to initiation of survey. Once the appropriate adjustments were made, in-depth, face-to-face oral interviews were conducted by registered nurses, nursing assistants, nursing students, and medical doctors completing their social service requirement for graduation. The research coordinator and staff trained 164 interviewers to administer the survey in a manner that would minimize interviewer bias and maximize consistency by reading questions exactly as written, in a nonleading manner, and prompting when needed with neutral statements. Each interviewer was assigned a finite number of interviews based on the estimated birth rate per hospital $3 \%$ of the estimated births for each hospital for the study year) and number of interviewers assigned to each hospital.

Interviews were conducted daily, one hour prior to hospital discharge for each postpartum woman. The questionnaires were kept in a secured site in the hospital, collected weekly by the research coordinator, and transported to the Proyecto Niños Saludables/Project Healthy Children office to be stored in a secure site until data input initiated.

\section{Data collection}

A total of 2619 women participated in the interviews. Data from the completed interviews were entered manually into EpiInfo 6 (CDC, Atlanta, Georgia, United States), and transferred into SPSS version 14.0 (SPSS Inc., Chicago, Illinois, United States) for analysis.

\section{RESULTS}

\section{Demographics}

Survey respondents were from 11 to 48 years of age, with the majority of respondents either 16-19 years of age $(24.7 \%)$ or $20-24$ years of age $(33.3 \%)$. When asked their ethnicity, 97.1\% of the respondents indicated mestiza (mixed heritage, Spanish/Indigenous/ African). More than three quarters of respondents $(80.5 \%)$ indicated sharing a home with the father of their newborn. The highest education level of most respondents was either incomplete primary school education $(31.1 \%)$ or complete primary school education $(39.2 \%)$. More than half $(64.8 \%)$ indicated that they did not work outside the home. The reported monthly income of $17.6 \%$ of respondents was from 100 to 1200 Honduran Lempiras (HNL) (US\$ 3.00-80.00 in 2001); 68.0\% from 1 201-6 $000 \mathrm{HNL}$ (US\$ 81-400); 5.8\% from 6 001-12 000 HNL (US\$ 401-800); and 0.9\% from 1 201-35 000 HNL (US\$ 801-\$2 333). Approximately $7 \%$ of respondents did

TABLE 1. List of hospitals for sampling in study of folic acid knowledge, attitudes, and practices (KAP) among postpartum women, Honduras, 2001

\begin{tabular}{lrrr}
\hline \multicolumn{1}{c}{ Hospital } & $\begin{array}{c}\text { Total } \\
\text { hospital } \\
\text { births }\end{array}$ & $\begin{array}{c}3 \% \text { of } \\
\text { hospital } \\
\text { births }\end{array}$ & $\begin{array}{c}\text { Hospital } \\
\text { interviews }\end{array}$ \\
\hline Hospital Materno Infantil & 13864 & 415 & 460 \\
Hospital General San Felipe & 5937 & 178 & 228 \\
Hospital Gabriela Alvarado & 2434 & 74 & 120 \\
Hospital Santa Teresa & 3799 & 114 & 134 \\
Hospital Leonardo Martinez & 6012 & 180 & 224 \\
Hospital del Progreso & 2810 & 84 & 80 \\
Hospital de Sur & 3700 & 111 & 125 \\
Hospital Integral de Sta. Bárbara & 2389 & 72 & 74 \\
Hospital Atlántida & 3748 & 112 & 118 \\
Hospital de Tocoa & 1975 & 60 & 65 \\
Hospital San Francisco & 2364 & 71 & 128 \\
Hospital Mario Catarino Rivas & 8496 & 255 & 206 \\
Hospital de Salvador Paredes & 573 & 17 & 182 \\
Hospital Regional de Occidente & 5076 & 152 & 38 \\
Hospital Gracias Lempira & 1240 & 37 & 49 \\
Hospital San Marcos Ocotepeque & 1365 & 41 & 203 \\
Maternidad del IHSS/ SPSa & 6784 & 203 & 157 \\
Maternidad del IHSS/ Teguc & 5494 & 165 & 2619 \\
Total & 78068 & 2341 & \\
\hline
\end{tabular}

a Instituto Hondureño de Seguridad Social/San Pedro Sula.

b Instituto Hondureño de Seguridad Social/ Tegucigalpa. 
not know their monthly income. The majority of this cohort indicated that their income was subsistence based.

\section{Prenatal care: knowledge, attitudes, and practices}

When asked whether they had received some kind of prenatal care, $88.5 \%$ of respondents indicated that they had. Of these, $50.2 \%$ had $1-5$ prenatal care visits, while $47.1 \%$ had $6-10$ visits. More than half (59.8\%) had prenatal care at a public clinic. The majority of the respondents $(90.2 \%)$ indicated they had been given vitamins; $72.6 \%$ said a doctor had told them to take vitamins. Of those who had been given vitamins, the largest percentages received them in either the second $(22.3 \%)$ or third $(23.0 \%)$ month of pregnancy, while only a small number reported receiving vitamins either before pregnancy $(0.2 \%)$ or in the first month (14.6\%) (Table 2).

\section{Folic acid: knowledge, attitudes, and practices}

When asked specifically about folic acid, $46.4 \%$ of respondents had heard of it, with the majority of those (68.6\%) having heard about it from a health care provider. When asked what they had heard about folic acid, the most common responses were that it helped avoid birth defects and/or was good for the growth and development of the baby $(37.6 \%)$, was a vitamin or was related to anemia or iron $(24.1 \%)$, was good for the baby $(22.9 \%)$, or good for health in general $(7.8 \%)$. When discussing folic acid consumption, $55.2 \%$ of the respondents indicated they had received folic acid before or during pregnancy, while $44.5 \%$ indicated they had not received folic acid at all. The largest number of respondents who did receive folic acid had received it in their second $(21.6 \%)$ or third month $(21.4 \%)$ of pregnancy (Table 2). Of those who reported having received folic acid, $97.4 \%$ reported taking it daily. The

TABLE 2: Selected survey items and responses in study of folic acid knowledge, attitudes, and practices among postpartum women, Honduras, 2001

\begin{tabular}{|c|c|c|}
\hline \multirow[b]{2}{*}{ Item } & \multicolumn{2}{|c|}{ Respondents } \\
\hline & No. & $\%$ \\
\hline \multicolumn{3}{|c|}{$\begin{array}{l}\text { Received prenatal care (number of visits), } \\
\qquad n=2317\end{array}$} \\
\hline $1-5$ & 1161 & 50.2 \\
\hline $6-10$ & 1092 & 47.1 \\
\hline$>11$ & 22 & 0.8 \\
\hline Don't know & 2 & 0.1 \\
\hline Refused & 40 & 17.0 \\
\hline \multicolumn{3}{|c|}{$\begin{array}{l}\text { Where received prenatal care, } \\
\qquad n=2317\end{array}$} \\
\hline Public clinic & 1385 & 59.8 \\
\hline Hospital & 388 & 16.7 \\
\hline Private clinic & 369 & 15.9 \\
\hline Other & 115 & 5.0 \\
\hline Don't know & 52 & 2.2 \\
\hline \multicolumn{3}{|c|}{$\begin{array}{l}\text { When received vitamins (month of pregnancy), } \\
\qquad n=2362\end{array}$} \\
\hline Before pregnancy & 5 & 0.2 \\
\hline First & 346 & 14.6 \\
\hline Second & 527 & 22.3 \\
\hline Third & 543 & 23.0 \\
\hline Fourth & 322 & 13.6 \\
\hline Fifth & 197 & 8.3 \\
\hline Sixth & 170 & 7.2 \\
\hline Seventh & 96 & 4.1 \\
\hline Eighth & 59 & 2.5 \\
\hline Ninth & 12 & 0.5 \\
\hline Don’t know & 85 & 3.6 \\
\hline \multicolumn{3}{|c|}{$\begin{array}{l}\text { When received folic acid (month), } \\
\qquad n=1451\end{array}$} \\
\hline Before pregnancy & 3 & 0.2 \\
\hline First month & 193 & 13.3 \\
\hline Second month & 314 & 21.6 \\
\hline Third month & 311 & 21.4 \\
\hline Fourth month & 176 & 12.1 \\
\hline Fifth month & 111 & 7.6 \\
\hline Sixth month & 115 & 7.9 \\
\hline Seventh month & 82 & 5.7 \\
\hline Eighth month & 57 & 3.9 \\
\hline Ninth month & 17 & 1.2 \\
\hline Don’t know & 72 & 5.0 \\
\hline
\end{tabular}

majority of respondents $(87.7 \%)$ reported that a doctor told them to take folic acid. Of the women surveyed, $62.3 \%$ indicated using some kind of medication during their pregnancy.

\section{Birth defects: knowledge, attitudes, and practices}

When asked why infants are born with birth defects, $23.0 \%$ of respondents related the causes to superstitious, mythical, or religious beliefs such as watching an eclipse, laughing at people with disabilities or the will of God. Alcohol, drugs, or medications not prescribed by a physician were mentioned by $20.6 \%$ of respondents, while a lack of vitamins or improper nutrition was mentioned by $18.1 \%$ of respondents. Lack of prenatal care or not taking care of oneself was mentioned by $16.3 \%$, while $22.1 \%$ of respondents indicated that they did not know or remember what causes birth defects. When asked whether birth defects could be prevented, $68.5 \%$ indi- 
cated that they could be. When asked how they could be prevented, $36.6 \%$ of respondents indicated prenatal care and/or taking care of oneself. Another $20.4 \%$ of respondents indicated consuming vitamins and eating well; $20.4 \%$ indicated avoidance of alcohol, drugs, and medications not prescribed by a physician; and $15.4 \%$ believed that engaging in mystical, mythical, and/or religious practices, such as wearing red during an eclipse or praying to God for a healthy child, could prevent birth defects.

\section{Food frequency items}

Although researchers asked women about their consumption of a wide variety of food items, for the purposes of this report, only those that have the potential to be fortified or are naturally high sources of folate have been included. Respondents were asked how often and what serving size of each food product they consumed, but for purposes of this data analysis, food consumption responses were categorized as "yes" to indicate consumption or "no."

Three quarters $(77.5 \%)$ of respondents reported drinking natural juice, $64.1 \%$ juice from concentrate, and $90.5 \%$ reported eating oranges. Nearly all $(94.2 \%)$ reported eating red beans, but very few $(10.8 \%)$ consumed peas, garbanzo beans, or lentils. Regarding vegetable consumption, $24.5 \%$ of respondents indicated eating broccoli and only $4.9 \%$ eating spinach. Half of the women $(50.6 \%)$ consumed lettuce. The type of lettuce was not specified in the survey because iceberg lettuce was the only type available in public markets at the time of the study.

Both corn and white flour tortillas are widely consumed in Honduras, but they are prepared in different ways. The nixtamalizado tortilla is made directly from corn variety. The kernels are first boiled with lime, washed, ground in manual grinders, and then made into a tortilla. Corn tortillas can also be made directly from packaged corn flour that is mixed with water and then made into a tortilla. White flour tortillas are either prepared from a mixture of white flour, lard, salt, baking soda, and water or bought prepackaged. In all, $83.1 \%$ of respondents reported consuming nixtamalizado corn tortillas, $34.4 \%$ reported consuming packaged corn-flour tortillas, and 58\% reported consuming white flour tortillas. When it came to other grain products, $62.5 \%$ of the respondents consumed white bread, while only $16.6 \%$ consumed whole wheat bread. Other frequently consumed staple foods were spaghetti $(87.4 \%)$; rice (95.2\%); and crackers, pastries, and sweet breads $(73.8 \%)$. In keeping with a Honduran tradition used to stimulate the production of breast milk, approximately $54 \%$ of respondents indicated consuming an oatmeal-based beverage exclusively during pregnancy and the postpartum months; however, overall, breakfast cereals were not widely consumed. Only $12.9 \%$ of women indicated that they consumed cereals such as granola, fiber, or ground wheat; 27.7\% consumed Central American cereals (less fortified); and only $4.7 \%$ consumed North American cereals (more fortified).

The consumption frequency of selected staple food items that have the potential to be fortified were analyzed in relation to the respondents' monthly incomes (Table 3). Consumption of rice and tortillas was high for all respondents regardless of income level. There were differences by income group, however, when further segmenting by type of tortilla product. Consumption of nixtamalizado corn tortillas was highest among the lower-income groups, while consumption of the packaged corn-flour tortillas was highest among the higher-income groups. Spaghetti and white bread were widely consumed regardless of income level. Consumption of the more costly whole wheat bread was higher among the higher-income groups.

\section{DISCUSSION}

It is of importance to note that at the time of this study, the Ministry of Health's Norm for folic acid consumption was limited to pregnant women for the prevention of megaloblastic anemia (24). Although more than half of the women reported receiving folic acid, only $0.2 \%$ of these women reported receiving it before pregnancy. Nearly three-quarters of the women who reported consuming vitamins during their pregnancy had received them from a physician. These data highlight the willingness of these women to consume vitamins given to them by their physicians, and underscore the important role that physicians can play in educating female patients about folic acid and encouraging its consumption among this popula-

TABLE 3. Consumption of selected fortifiable food products by respondent's income level, folic acid knowledge, attitudes, and practices among postpartum women study, Honduras, 2001

\begin{tabular}{|c|c|c|c|c|c|c|c|c|}
\hline \multirow[b]{2}{*}{ Food consumed } & \multicolumn{2}{|c|}{$\begin{array}{c}\text { Income } \\
\text { level } 1.00^{a} \\
(n=460) \\
\end{array}$} & \multicolumn{2}{|c|}{$\begin{array}{c}\text { Income } \\
\text { level } 2.00^{\mathrm{b}} \\
(n=1780)\end{array}$} & \multicolumn{2}{|c|}{$\begin{array}{c}\text { Income } \\
\text { level 3.00c } \\
(n=153)\end{array}$} & \multicolumn{2}{|c|}{$\begin{array}{l}\text { Income } \\
\text { level 4.00d } \\
(n=24)\end{array}$} \\
\hline & No. & $\%$ & No. & $\%$ & No. & $\%$ & No. & $\%$ \\
\hline Rice & 428 & 93.0 & 1706 & 95.8 & 145 & 94.8 & 24 & 100.0 \\
\hline Corn tortilla (nixtamalizado) & 425 & 92.4 & 1443 & 81.1 & 111 & 72.5 & 15 & 62.5 \\
\hline Corn flour tortilla (packaged) & 121 & 26.3 & 653 & 36.7 & 69 & 45.1 & 11 & 45.8 \\
\hline White flour tortilla (packaged) & 219 & 47.6 & 1057 & 59.4 & 94 & 61.4 & 14 & 58.3 \\
\hline Spaghetti & 383 & 83.3 & 1562 & 87.8 & 137 & 89.5 & 23 & 95.8 \\
\hline White bread & 255 & 55.4 & 1132 & 63.6 & 106 & 69.3 & 19 & 79.2 \\
\hline Whole wheat bread & 62 & 13.5 & 270 & 15.2 & 55 & 35.9 & 9 & 37.5 \\
\hline
\end{tabular}

\footnotetext{
a Monthly household income of 100-1200 Lempira (US \$3-\$80).

${ }^{b}$ Monthly household income of 1 201-6 000 Lempira (US \$81-\$400).

${ }^{c}$ Monthly household income of $6001-12000$ (US $\$ 401-\$ 800$ ).

d Monthly household income of 12 001-35 000 Lempira (US \$801-\$2 333).
} 
tion. Educating women about folic acid and the need to take it before conception is just as essential to a comprehensive folic acid initiative as is educating the providers about folic acid benefits.

More than one-half of the women in this study reported that they had heard about folic acid. Of these, more than one-third associated it with preventing defects and/or good growth and development of the baby; and one-quarter identified it as a vitamin, associated it with anemia, or associated it with iron. Given that birth defects are multicausal, it is encouraging that more women associated taking vitamins, eating well, and/or avoiding alcohol and drugs with prevention of birth defects, rather than with supernatural practices such as wearing red during an eclipse. Understanding the scientific causes of birth defects and being able to make a connection between birth defects and prevention is an important educational component that may still be lacking among the respondent population. Without knowing the rationale for taking folic acid, it could be less likely that women in this target population would sustain the behavior. Providing women with accurate folic acid education is an important step to ensuring folic acid intake both before pregnancy and throughout their reproductive years.

In Honduras, multiple social and economic factors make the sustainability of a supplementation program more challenging. The combination of a very young population, high poverty and illiteracy rates, and a primarily rural population can be significant challenges to distributing the folic acid supplement and reaching an audience with a health message. Several possible avenues have been identified to overcome such barriers. One would be the use of volunteer lay health workers known as promotoras, madres guias, or madres maestros. These volunteers could work within their own communities as well as surrounding communities. The possibility of linking promotora-led folic acid supplementation and education efforts to existing successful programs, such as the country-wide immunization program, is another avenue worth exploring. Religious and secular associations, both national and international, have built trust with hard-to-reach communities and established infrastructures that could lend themselves to a sustainable combined education and supplementation program. Rural communities and even barrios (neighborhoods) within large cities have their own patronatos (steering committees) elected by community members to oversee the well-being of the community. Education directed at members of these groups would allow for dissemination of education materials by those who are already trusted, thereby increasing the likelihood of the program's sustainability.

As mentioned previously, a major concern of any folic acid effort in Honduras is reaching a population that is largely rural and primarily subsistencebased. Fortification of corn flour used to make tortillas would allow folic acid to reach a certain portion of the population. Findings from this study indicate a higher consumption of packaged white-flour tortillas than packaged corn-flour tortillas, underscoring the benefit of the 2003 Central American mandate requiring wheat flour fortification. White bread consumption was widespread with the highest consumption among the highest income level, while whole wheat bread was less frequently consumed by the population regardless of income level. Spaghetti was found to be a very highly consumed product among all income levels. Fortifying pasta products, then, could be a potential avenue for reaching a large segment of the population. It is important to consider, however, that food consumption can potentially vary between regions of the country. A study conducted by the Pediatric Medical Mission University of Armed Services (38) suggests that the use of flour products is found more in urban than rural areas. Researchers conducting home visits found no wheat flour or wheat flour products in any of the homes in rural communities surrounding La Paz, Honduras (38). Finding those food products that are staple to a country, regardless of region, can help ensure that fortification efforts reach the widest possible audience.

Holden and colleagues (16) found that given the frequency of rice and tortilla (non-specified type) consumption, fortifying these staple products with folic acid could prevent a high number of NTDs. Similarly, the current study found very high consumption of rice and tortillas, although a higher percentage of women consumed the nixtamalizado tortillas than any other type. Because this type of tortilla is essentially hand processed directly from the corn kernel, fortification may be more challenging. Holden (16) stated in his article that one potential method of fortification for the nixtamalizado tortillas widely consumed in rural communities is adding folic acid to the water used to wash the corn before grinding, because most women use a community grinding machine for that purpose. A 2002 study by INCAP (39) explored this method of fortification in rural Guatemalan communities. While fortification with this method was found to be successful, lack of funding to further explore quality control issues regarding over- or under- fortification of the product have yet to be examined (Dr. Rubén Grajeda, personal communication, September 2004).

Given the socioeconomic challenges this country faces, fortification alone may not be effective in reaching all of the population or in providing the recommended daily levels needed for NTD prevention. Yet, without the full implementation of a folic acid fortification program, it is difficult to assess which avenues are most effective and where the gaps in reaching the population exist. While Honduras has been included in some studies looking at potential fortification efforts, these studies have primarily centered on iron fortification (21). Research examining the impact of folic acid fortification efforts is necessary.

Combining fortification and supplementation efforts may be the most effective way to maximize resources and reach the largest number of Honduran women. Developing and implementing a strong folic acid education program and integrating this educational com- 
ponent with the fortification and supplementation efforts can help to ensure awareness of folic acid, acceptance of the folic acid message, and compliance with the program recommendations.

In this study, nearly half of the women interviewed were aware of folic acid due to the emphasis placed on the prevention of megaloblastic anemia at that time by the Honduran Health System. However, fewer than half associated folic acid with fetal development. A strong foundation of folic acid education would maximize the effects of a national supplementation campaign designed to increase folic acid consumption. Similarly, a nutrition education component emphasizing natural folate sources and fortified food products could increase the overall health of women of childbearing age.

There are limitations to this study. Findings are based on the responses of a convenience sample of postpartum women who agreed to participate in the study. Having just been through a pregnancy, these women may be more knowledgeable about folic acid than the general population. Moreover, findings of this study do not reflect the knowledge and behaviors of Honduran women who lack access to prenatal care and hospital delivery. The income level of respondents is higher than the general population; therefore, the data cannot be generalized to the most resource-poor populations of Honduras. Because medical personnel conducted the surveys, the respondents may have been more likely to answer favorably to questions related to health care provider recommendations. Study respondents appear receptive to folic acid education and recommendations provided by their public health physicians; however, these physicians are not available to all Hondurans. Folic acid education and distribution strategies must be implemented with the disadvantages of this latter segment of the population in mind. Finally, for the food intake portion of the survey instrument, the respondent had to recall the portion size of a particular food item, as well as the frequency of its consumption, but because this might have led to inaccurate estimations, this data analysis categorized responses as either "yes," indicating consumption, or "no."

The findings of this study could be used to assist the Honduran government in making decisions regarding the selection of adequate vehicles for food fortification and how to proceed with a nationwide folic acid education effort. In a country such as Honduras, where there are significant challenges associated with socioeconomics, isolation due to rurality, and a primarily subsistence-based lifestyle, achieving the goal of increasing folic acid consumption will require a three-pronged approach-combining folic acid education with supplementation and fortification efforts. Possibilities for future research include the evaluation of the effectiveness of educational efforts, and alternative forms of folic acid supplements, such as sprinkles, or a combined folic acid and iron tablet. Furthermore, research related to NTD risk factors, such as genetic mutations and fumonisin, are also warranted.

\section{REFERENCES}

1. Centers for Disease Control and Prevention. Recommendations for the use of folic acid to reduce the number of cases of spina bifida and other neural tube defects. MMWR. 1992; 41(RR-14):1-7.

2. Williams LJ, Rasmussen S, Flores AL, Kirby R, Edmonds L. Decline in the prevalence of spina bifida and anencephaly by race-ethnicity, 1995-2002. Pediatrics. 2005;166:580-6.

3. Kirby R, Petrini J, Alter C, The Hispanic Ethnicity Birth Defects Workgroup. Collecting and interpreting birth defects surveillance data by Hispanic ethnicity: A comparative study. Teratology. 2000;61:21-7.

4. Mutchinick OM, López MA, Luna L, Waxman J, Babinsky VE, RYVEMCE Collaborative Group. High prevalence of the thermolabile methylenetetrahydrofolate reductase variant in Mexico: A country with a very high prevalence of neural tube defects. Mol Gen and Metab. 1999;68:461-7.

5. The Gallup Organization for the National March of Dimes Birth Defects Foundation. Preparing for pregnancy III: Third national survey of women's behavior and knowledge relative to consumption of folic acid and other vitamins and pre-pregnancy care. 1998;March of Dimes: White Plains NY.(Report number 31-1154-98).

6. Ahluwalia IB, Lyon Daniel K. Are women with recent live births aware of the benefits of folic acid? MMWR. 2001;50(RR06):3-14.

7. Pérez-Escamilla R, Himmelgreen D, SeguraMillán S, González A, Méndez I, Haldeman L. Knowledge of folic acid and neural tube defects among inner-city residents: Have they heard about it? Research and Professional Briefs. J Am Diet Assoc. 1999; 99(1):80-3.

8. Carmichael SL, Shaw GM, Yang W, Laurent C, Herring A, Royle H, et al. National birth defects prevention study: Correlate of intake of folic acid-containing supplements among pregnant women. Am J Obst Gyn. 2006; 194: 203-10.

9. Jasti S, Siega-Riz AM, Bentley ME. Dietary supplement use in the context of health disparities: Cultural, ethnic and demographic determinants of use. J Nutr. 2003;133:2010S2013S.

10. Balluz LS, Kieszak SM, Philen RM, Mulinare J. Vitamin and mineral supplement use in the United States: Results from the Third National Health and Nutrition Examination Survey. Arch Fam Med; 2000:9:258-62.
11. Secretaria de Salud. Situación de salud en Honduras: Indicadores básicos, 2004. Tegucigalpa Metro Distrito Central: El Instituto; 2005.

12. Milla G, Umaña E, Mayes I. Prevalencia hospitalaria de anomalías congénitas en Honduras [data presentation]. San Pedro Sula, Honduras: Proyecto Niños Saludables; 2002.

13. Milla G, Umaña E, \& Mayes I. Los costos hospitalarios directos de anomalías congénitas en Honduras [data presentation]. San Pedro Sula, Honduras: Proyecto Niños Saludables; 2003.

14. Instituto Nacional de Estadísticas. Censo nacional de población y vivienda. Tegucigalpa Metro Distrito Central: El Instituto; 2001.

15. Instituto Nacional de Estadísticas. Encuesta de hogares de propósitos múltiples. Tegucigalpa Metro Distrito Central: El Instituto; 2004.

16. Holden KR, Collins JS, Greene JF, Hinkle S, Nave AF, Portillo JM, et al. Dietary intake and blood folate levels in Honduran women of childbearing age. J Child Neurol 2002;17: 341-6.

17. Wu DY, Brat G, Milla G. Folic acid knowledge and usage amongst region number 3 patients and health workers in Honduras [data presentation]; San Pedro Sula, Honduras: Proyecto Niños Saludables; September 2004. 
18. Hertrampf E, Cortés F, Erickson JD, Cayazzo $\mathrm{M}$, FreireW, Bailey LB, et al. Consumption of folic acid-fortified bread improves folate status in women of reproductive age in Chile. Jnl of Nutr. 2003;133:3166-9.

19. Ray JG, Cole DE, Boss SC. An Ontario-wide study of vitamin B12, serum folate, and red cell folate levels in relation to plasma homocysteine: Is a preventable public health issue on the rise? Clin Biochem. 2000;33(5): $337-43$.

20. Comisión de Ministros de economía de Centroamérica. Reglamento técnico de la unión aduanera centroamericana 2002, XXIV. (R-UAC 67.01.15.12).

21. Darnton-Hill I, Mora JO, Weinstein H, Wilbur $S$, Nalubola PR. Iron and folate fortification in the Americas to prevent and control micronutrient malnutrition: An analysis. Nutrl Rev. 1999;57(1):25-31.

22. Secretaria de Salud Marca Registrada (MASECA Registro Sanitario Hondureño RSA 3-0006187-02-2005) Departamento de Regulación, Secretaria de Salud. Tegucigalpa DC, Honduras.

23. Secretaria de Salud. Normas nacionales de atención materna-neonatal. Tegucigalpa Metro Distrito Central: El Instituto; 2005.

24. Secretaria de Salud de Honduras. Manual de normas y procedimientos de atención integral a la mujer. Tegucigalpa Metro Distrito Central: El Instituto; 1999

25. Secretaria de Salud, Asociación Hondureña de Planificación de Familia (ASHONPLAFA), la Agencia de los Estados Unidos para el Desarrollo Internacional (USAID). Encuesta nacional de epidemiología y salud familiar. Tegucigalpa MDC: El Instituto; 2001.

26. Al-Gazali LI, Szthriha L, Dawodu A, Bakir M, Varghese M, Varady E, et al. Patterns of central nervous system anomalies in a population with high rate of consanguineous marriage. Clin Gen. 1999;55(2):95-102.

27. Tolarova M. Genetics, Gene Carriers, and Environment. In: Bader JD (ed). Risk Assessment in Dentistry. Chapel Hill: University of North Carolina; 1990. Pp. 116-79.

28. Becerra, JE, Khoury,MJ, Cordero,JE, Erickson JD. Diabetes mellitus during pregnancy and the risks for specific birth defects: A population based case-control study. Pediatrics. 1990;85:1-9.

29. CDC. Valproate: A new cause of birth defect-Report from Italy and follow-up from France. MMWR. 1983;32(33):438-9.

30. Covani A, Gupta AK, Jeavons PM. Sodium valproate: monotherapy and polytherapy. Epilepsia. 1982;6:693--720.

31. Jeavons PM. Non dose related side effects of valproate. Epilepsia. 1984;25(Suppl 1):S50-5.

32. Garcia AM, Fletcher T, Benavides FG, Orts E. Parental agricultural work and selected congenital malformations. Am J of Epi. 1999; 149(1):64-73.

33. Goodman MR, Gorlin JR. Fetal environment syndromes. In: Goodman MR, Gorlin JR. The malformed infant and child. New York: Oxford University Press; 1983. Pp. 11-36.
34. Reece EA, Homko CJ, Wu YK, Wiznitzer A The role of free radicals and membrane lipids in diabetes-induced congenital malformations. J Soc Gyn Inves. 1988;5(4):178-87.

35. Restrepo M, Munoz N, Day N, Parra JE, Hernandez $C$, Blettner $M$, et al. Birth defects among children born to a population occupationally exposed to pesticides in Columbia. Scand J Work Environ. 1990;(4):232-8.

36. Shaw GM, Velie EM, Morland KB. Parental recreational drug use and risk for neural tube defects. Am J. Epidemol. 1996;144(12):1155-60.

37. Wasserman C, Shaw G, Selvin S, Gould J Syme S. Socioeconomic status, neighborhood social conditions, and neural tube defects. Amer J Public Health. 1998;(11):1674-80.

38. Lynch J, Kemmer T, Lougee D. Pediatric Nutrition Medicine Missions. San Antonio Texas: Armed Services University of Health Services. 2001.

39. De León L, Romero ME. Fortificación de maíz nixtamalizado con hierro y ácido fólico a nivel de molinos comunitarios: Desarrollo de tecnología y aceptabilidad al consumidor. Available from: http://www.bvssan.incap.org.gt/ bvs_incap/E/pubtec.htm. Accessed 13 March 2006.

Manuscript received on 31 July 2006. Revised version accepted for publication on 16 October 2007.

RESUMEN Objetivos. Este estudio tuvo dos propósitos: primero, determinar los conocimientos, las actitudes y las prácticas relacionados con el ácido fólico y las malformaciones congénitas en una muestra de conveniencia de mujeres hondureñas recién paridas; y segundo, identificar los patrones de consumo de alimentos en esta población y determinar los productos básicos de alto consumo para su posible fortificación con ácido fólico. Métodos. Se seleccionaron las posibles participantes mediante un muestreo de conveniencia. Participaron 2619 mujeres hondureñas que habían tenido un parto normal en alguno de los 16 hospitales públicos del país o de dos hospitales de la seguridad social que prestan servicios a la clase trabajadora hondureña. En un período de 10 meses se realizaron entrevistas personales directas, orales y exhaustivas en los propios hospitales antes del alta médica. El coordinador y el equipo de investigación supervisaron las entrevistas.

Resultados. La mayoría de las mujeres tenían entre 16 y 29 años de edad. Aproximadamente la mitad de las encuestadas $(46,4 \%)$ habían oído sobre el ácido fólico y más de la tercera parte $(37,6 \%)$ sabía que era una vitamina relacionada con la prevención de malformaciones congénitas. Las mujeres encuestadas atribuyeron estas malformaciones principalmente al consumo de drogas y alcohol $(20,6 \%)$ y a la insuficiente ingesta de vitaminas (18,1\%); no obstante, 23,0\% relacionó las malformaciones con causas místicas, míticas o religiosas. En esta población no se consumen muchos alimentos ricos en folatos, excepto frijoles colorados, naranjas y jugos de frutas naturales. Los alimentos básicos más frecuentes que podrían fortificarse con ácido fólico fueron el arroz, las pastas y las harinas de trigo y de maíz.

Conclusiones. Los resultados de este estudio abren una posible vía para la fortificación de alimentos y, además, subrayan la necesidad de una mayor educación sobre la importancia del ácido fólico en la prevención de malformaciones del tubo neural en los fetos. Los resultados destacan la necesidad de ofrecer una educación sanitaria estandarizada a las mujeres hondureñas en edad reproductiva si se implementa de manera exitosa y sostenible el consumo de ácido fólico mediante la fortificación y suplementación de alimentos.

Palabras clave Ácido fólico, fisiología de la nutrición prenatal, defectos del tubo neural, Honduras. 